\title{
THE EFFECT OF ORGANIC SELENIUM ON HAEMATOLOGICAL AND BIOCHEMICAL PARAMETERS OF BLOOD AND THE QUALITY OF PHEASANT BREAST MEAT
}

\author{
Saša Obradovićc ${ }^{*}$, Branko Petrujkić ${ }^{2}$, Vladan Đermanović3 \\ Vladimir Živković ${ }^{4}$, Bojan Stojanovićs ${ }^{3}$ Nenad Đorđevićs ${ }^{3}$ Milanka Radulovićs \\ ${ }^{1}$ Faculty of Agriculture, Kruševac, University of Niš, Republic of Serbia \\ ${ }^{2}$ Faculty of Veterinary Medicine, University of Belgrade, Republic of Serbia \\ ${ }^{3}$ Faculty of Agriculture, University of Belgrade, Republic of Serbia \\ ${ }^{4}$ Institute for Animal Husbandry, Belgrade-Zemun, Republic of Serbia \\ ${ }^{5}$ State University of Novi Pazar, Department of Biomedical \\ Sciences, Novi Pazar, Republic of Serbia
}

\section{Abstract}

The aim of this study was to determine the effect of supplementing food with various concentrations of organic selenium $(0.2$ and $0.3 \mathrm{mg} / \mathrm{kg}$ diet $)$ on the biochemical and haematological parameters of blood and the quality of breast meat of 45 pheasants. The pheasants were divided into three groups and fed mixtures containing organic selenium supplementation in the concentrations of $0.2 \mathrm{mg} / \mathrm{kg}$ ( $1^{\text {st }}$ group) and $0.3 \mathrm{mg} / \mathrm{kg}\left(2^{\text {nd }}\right.$ group) and a mixture without selenium in a control group (K). After 60 days of the experiment, it was determined that the average values of selenium content in the breast meat and blood serum of the $2^{\text {nd }}$ group of pheasants which were fed $0.3 \mathrm{mg} / \mathrm{kg}$ of organic selenium were significantly higher $(\mathrm{p}<0.05)$ than the same parameters of the pheasants from $\mathrm{K}$ group. The pheasants from the $2^{\text {nd }}$ group also had better sensory traits of meat and they had the highest difference of the sum of the ranks of meat acceptability. The difference was by 15 points higher than that in the K group and 7 points higher than in the meat of the pheasants from the $1^{\text {st }}$ group that fed $0.2 \mathrm{mg} / \mathrm{kg}$ of selenium. The addition of organic selenium supplementation to the diet for the $2^{\text {nd }}$ group of pheasants $(0.3 \mathrm{mg} / \mathrm{kg})$ increased the water retention capacity in breast

${ }^{1 *}$ Corresponding Author: sasaobradovic1@gmail.com 
meat by $0.75 \%$ compared to the K group, namely by $0.58 \%$ in comparison to the $1^{\text {st }}$ group. The average values of chemical parameters of meat $(\mathrm{pH}$, water, fat, proteins and ash content), haematological parameters of pheasant blood (number of erythrocytes, leucocytes and platelets, haemoglobin and haematocrit values) and biochemical parameters of blood serum (glucose, enzymes: aspartate transaminase and alanine aminotransferase, total protein concentration, total cholesterol albumin, triglycerides, calcium, potassium and sodium) were within the limits of reference values for pheasants and very uniform without significant variations among experimental groups.

Key words: pheasant, breast meat quality, biochemical and haematological profile

\title{
EFEKAT DODAVANJA ORGANSKOG SELENA NA HEMATOLOŠKE I BIOHEMIJSKE PARAMETRE KRVI I KVALITET GRUDNOG MESA FAZANA
}

\author{
Saša Obradović ${ }^{1}$, Branko Petrujkić ${ }^{2}$, Vladan Đermanović ${ }^{4}$, \\ Vladimir Živković ${ }^{3}$, Bojan Stojanović ${ }^{4}$, Nenad Đorđević ${ }^{4}$, Milanka Radulović 5 \\ ${ }^{1}$ Poljoprivredni fakultet, Kruševac, Univerzitet u Nišu, Republika Srbija \\ ${ }^{2}$ Fakultet veterinarske medicine, Univerzitet u Beogradu, Republika Srbija \\ ${ }^{3}$ Institut za stočarstvo, Beograd-Zemun, Republika Srbija \\ ${ }^{4}$ Poljoprivredni fakultet, Univerzitet u Beogradu, Republika Srbija \\ ${ }^{5}$ Državni univerzitet u Novom Pazaru, Departman za \\ biomedicinske nauke, Novi Pazar, Republika Srbija
}

\section{Kratak sadržaj}

Cilj rada je bio da se ispitaju biohemijski i hematološki parametri krvi, kao i kvalitet grudnog mesa 45 fazana podeljenih u tri grupe i hranjenih smešama sa dodatkom organskog selena u koncentracijama od $0.2 \mathrm{mg} / \mathrm{kg}$ (I grupa) i $0.3 \mathrm{mg} / \mathrm{kg}$ (II grupa) u hrani i smešom bez selena u kontrolnoj grupi (K). Nakon 60 dana trajanja ogleda utvrđeno je da su prosečne vrednosti sadržaja selena u belom mesu i sadržaja selena u krvnom serumu fazana II grupe fazana hranjenih sa $0.3 \mathrm{mg} / \mathrm{kg}$ organskog selena značajno veće ( $\mathrm{p}$ > 0.05) u odnosu na iste parametre fazana grupe K. Fazani II grupe su takođe imale bolje senzorne osobine mesa i ostvarile su najveću razliku sume ran- 
gova prihvatljivosti mesa, koja je bila veća za 15 bodova od $\mathrm{K}$ grupe i 7 bodova od mesa fazana hranjenih sa $0.2 \mathrm{mg} / \mathrm{kg}$ selena. Dodavanje organskog selena u hranu fazana II grupe $(0.3 \mathrm{mg} / \mathrm{kg})$ je imalo pozitivan efekat na povećanje sposobnosti zadržavanja vode u grudnom mesu za $0.75 \%$ u odnosu na K grupu, odnosno za $0.58 \%$ u poređenju sa I grupom. Prosečne vrednosti hemijskih parametara mesa $(\mathrm{pH}$, sadržaj vode, masti, proteina i pepela), hematoloških parametara krvi fazana (broj eritrocita, leukocita i trombocita, vrednosti hemoglobina i hematokrita) i biohemijskih parametara krvnog seruma (glukoze, enzima: aspartat aminotransferaza i alanin aminotransferaza, koncentracije ukupnih proteina, albumina ukupnog holesterola, triglecirida, kalcijum, kalijum i natrijum) bile su u granicama referentnih vrednosti za fazane i vrlo ujednačenih vrednosti bez signifikantnih razlika između ispitivanih grupa.

Ključne reči: fazan, kvalitet belog mesa, biohemijski i hematološki profil

\section{INTRODUCTION}

Pheasant farming is a branch of agriculture that is developing worldwide. Due to its favourable nutritional constituents, pheasant meat is the food that is increasingly used in human nutrition. At the same time, pheasant hunting is a very popular sport. Bird and poultry meat is particularly important for human nutrition, primarily because of its high quality proteins, minimum amount of fat, essential vitamins and minerals.

Biochemical and haematological blood parameters are significant for successful farm production, because the health condition of farmed birds, their nutritive status, the content of certain nutrients as well as symptoms of disease can be assessed using these parameters. Avian haematology is also a useful diagnostic tool in veterinary medicine and haematological values can be used as physiological indicators. Several papers dealing with haematological and biochemical parameters of pheasant blood have been published so far (Šperanda et al., 2005; Lloyd and Gibson, 2006; Tucak et al., 2008; Kececi and Ramazan, 2011).

Biochemical parameters and shaped blood elements of poultry have been examined in numerous papers, while the available literature data related to the issue of the effect and content of selenium in the blood of pheasants is scarce. Selenium (Se) is an essential microelement and an integral part of glutathione peroxidase enzyme (GPx) which plays a crucial role as antioxidant enzyme in antioxidant defence of free radicals in bird and mammal cells (Coles, 1977; Dukes, 1993; Edens, 2001). 
The physiological role of selenium is complex. It is primarily important for the development of numerous metabolic processes in the organisms of birds and mammals. It also has antioxidant role in health preservation and improving production performances. According to Surai (2000), selenium and vitamin E deficiency causes various diseases in about 60 species of domestic, wild and laboratory animals and humans. In modern food production for domestic animals, selenium supplementation is mandatory, and lately, significant research efforts have been made to increase selenium concentration in food, in order to obtain functional animal products (meat, eggs, milk) enriched with selenium.

Selenium deficiency and loss of GPx enzyme activity causes cell membrane damage, free radical accumulation and cell decay. The antioxidant effect of selenium protects poultry from atherosclerosis, degenerative processes of the pancreas and kidneys, reproductive disorders, tumorigenesis and at the same time selenium also has immunostimulatory effect (Dukes, 1993; Kang et al., 2000; Dlouha et al., 2008). The intake of selenium through food results in increased content of its concentration in tissues and eggs (Edens, 1997; Surai and Dvorska, 2002; Edens and Kymberly, 2004). Selenium deficiency in poultry causes numerous pathological changes and diseases, such as the pancreas atrophy, kidney damage, exudative diathesis, decreased fertilization and weakened immunity. Selenium is also an activator of thyroid hormones which are responsible for thermogenesis of poultry. The concentration of selenium in the organism of birds under heat stress can be significantly reduced (Silva and Gloria, 2002; Skrivan et al., 2008). Poultry and bird production depends on numerous stress factors (overpopulation, heat stress, diseases), which is why selenium, as an integral part of many selenoproteins, actively participates in their prevention by activating antioxidant mechanisms. The concentration of selenium in the tissue differs and primarily depends on the amount of selenium ingested with food whereby the highest amount of selenium of $30-40 \%$ is found deposited in skeletal muscles and the liver and the rest of it is in the heart, pancreas and kidneys (Surai, 2000; Surai and Dvorska, 2002).

Breast muscles (mm. pectoralis) known as breast meat, consist of larger superficial muscle (m. pectoralis superficialis) and a smaller deep muscle (m. pectoralis profundus) and they are extremely well-developed in all birds because they enable the movement of the wings and flying. Breast muscles account for one quarter of the total body weight of birds and a half of total edible proteins. Poultry and bird breast meat is rich in proteins, low in fat and cholesterol compared to the meat of other domestic animals which makes it a high quality dietary product (Barroeta, 2006). If poultry meat contains selenium 
in the concentration higher than prescribed, then the meat can be considered a functional food because it has beneficial effect on improving human health and lowering the risk of diseases.

Poultry and bird meat is significant for human nutrition because of its high content of biologically valuable proteins, fats, vitamins, minerals and essential fatty acids (Franco and Lorenzo, 2013). The smell, appearance and taste are very important sensory traits of meat, and these traits can significantly affect the quality and acceptability of the product by consumers. The smell and taste have the greatest impact on acceptability of meat, so the final judgment on its acceptability is mostly based on these traits. Sensory traits ranking by evaluators represent a simple method for practical comparison and assessment of meat samples or other products (Baltić, 1993; Baltić and Teodorović, 1997). Consumers want the meat with minimal water loss during preparation and cooking, and that is why the ability to retain water is an essential characteristic of meat quality (Surai, 2000; Edens et al., 2000; Surai, 2007).

There are few papers in the available literature dealing with the effects of organic selenium on breast meat quality, biochemical and haematological profile of blood of the pheasants which are fed different amounts of organic selenium. For that reason, the main goal of this paper is to examine the effect of organic selenium on selected haematological, biochemical parameters and selenium content in blood serum as well as the effect of selenium on chemical and sensory quality of pheasant breast meat.

\section{MATERIAL AND METHODS}

The experiment was conducted on 45 common pheasants (Phasianus colchicus), which were 42 days old, both male and female, weighing $385 \pm 75 \mathrm{~g}$ on average. They were divided into three groups each containing 15 pheasants. The experiment lasted for 60 days and during that period the pheasant barns and nutrition were adapted to the floor way of rising. We used pelleted complete feed mixtures for formulated for nutritional needs of pheasants (NRC, 1994). The organic selenium contained in Alkosel $^{\circledR}$ preparation (Lallemand, Fra) was added to the premixes, and after appropriate mixing, the premix with selenium was applied to the complete feed mixtures and mixed again with the complete mixture. The control group $(\mathrm{K})$ was fed the feed without selenium supplementation, while the feed of experimental $1^{\text {st }}$ group contained organic selenium in a concentration of $0.2 \mathrm{mg} / \mathrm{kg}$, and the feed of experimental $2^{\text {nd }}$ group contained organic selenium in the concentration of $0.3 \mathrm{mg} / \mathrm{kg}$. The raw material and chemical composition of pheasant food is shown in Table 1. 
Table 1. Ingredients and nutrient content of complete feed mixture for pheasants

\begin{tabular}{|c|c|c|}
\hline Components & $\%$ & \multirow{16}{*}{ 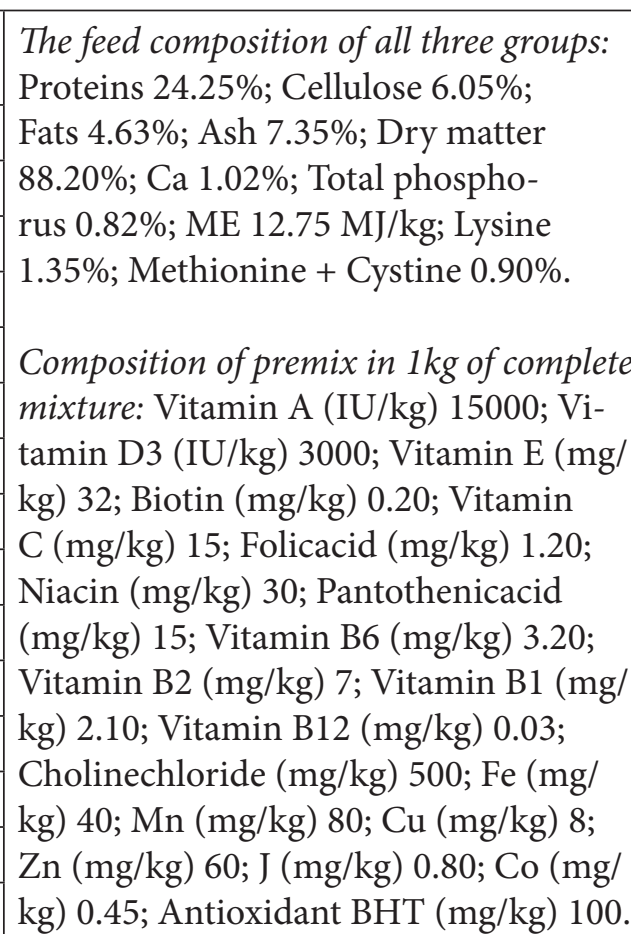 } \\
\hline Maize & 40 & \\
\hline Wheat bran & 3 & \\
\hline Soybean meal & 24 & \\
\hline Sunflower mea & 4.3 & \\
\hline Alfalfa meal & 3 & \\
\hline Yeast & 3.5 & \\
\hline Soybean grits & 12 & \\
\hline Sunflower meal $42 \%$ & 5 & \\
\hline Lysine & 0.1 & \\
\hline Methionine & 0.2 & \\
\hline Limestone & 1.6 & \\
\hline Mono-Ca-phosphate & 1.5 & \\
\hline Salt & 0.3 & \\
\hline Additive Pelletin & 0.5 & \\
\hline Premix & 1 & \\
\hline
\end{tabular}

Diet I (K group): basal diet without organic Se;

Diet II ( $1^{\text {st }}$ group $)$ - Diet I + organic Se at $0.2 \mathrm{mg} / \mathrm{kg}$ diet;

Diet III ( $2^{\text {nd }}$ group) -- Diet I + organic Se at $0.3 \mathrm{mg} / \mathrm{kg}$ diet;

Throughout the entire experiment, the consumption of food and water was ad libitum. An average sample of complete mixtures for pheasant nutrition was analysed for the basic chemical composition at the beginning of the experiment (the amount of dry matter, crude ash, crude proteins, crude fats and crude cellulose), by applying standard analytical methods of chemical food examination (AOAC, 1990). The content of calcium (Ca) was determined by volumetric method (SRPS ISO 6490-1/2001). Phosphorus (P) content was determined using spectrophotometric method (SRPS ISO 6491/2002), while the content of metabolic energy and amino acids was obtained by calculation based on their content in nutrients (INRA-AFZ, 2004).

Control measurements of body weight were performed on an electronic scale with an accuracy of $\pm 0.5 \mathrm{~g}$ at the beginning and the end of the experiment. This was used as a basis for calculating average body weight. Throughout the experiment, the health condition of pheasants and their mortality were 
monitored. By the method of random sampling at the end of this 60-day long experiment, seven pheasants were taken from each group. They were then individually measured before slaughtering, and after primary slaughter processing and water cooling, chilled carcasses were cut into basic pieces in a manner regulated by Ordinance on the Quality of Poultry Meat (Official Gazette SFRJ No. $1 / 81$ and 51/88), and the brest muscle was separated and measured on an automatic scale with an accuracy of $\pm 0.5 \mathrm{~g}$.

The water in the breast meat was analysed using standard examination methods. The total water content was determined by drying the samples to constant weight (SRPS ISO 1442/1998), total ash by burning and annealing the sample at the temperature of $500{ }^{\circ} \mathrm{C}$ to $600{ }^{\circ} \mathrm{C}$ (SRPS ISO 936/1999), $\mathrm{pH}$ of the meat were determined by a pH meter (SRPS ISO 2917: 2004), total proteins by the Kjedahl method based on nitrogen content (SRPS ISO 937/1992), while the total fat was determined by Soxlett extraction with pre-drying of the sample (SRPS ISO 1443/1992). The content of selenium in breast meat and blood serum of pheasants was determined by atomic absorption spectrophotometry using hydride technique (SRPS EN 14627:2008). The ability to retain water in breast meat was determined by measuring the content of total moisture, 24 and 48 hours after the time of meat cooling at $4{ }^{\circ} \mathrm{C}$. The quality of meat sensory traits was examined by the method for determination of the difference in meat acceptability using Rank test, assessed by 7 evaluators (Baltić, 1993; Baltić and Teodorović, 1997; SRPS EN ISO 8587/2006). The evaluators assessed the sensory characteristics of the meat (the smell, taste, juiciness, softness and appearance). The obtained differences in the acceptability of the meat are the differences in the overall impression of all evaluators. Before the examination, all the samples were grilled for about 15 minutes and after that the evaluators graded the samples labelling them the most acceptable, less acceptable and the least acceptable.

At the end of the experiment and before slaughtering, seven pheasants from each group, their blood were taken by puncturing the ulnar vein. The sterile tubes used for haematological tests contained the anticoagulant Sodium-Ethylenediaminetetraacetic acid (Na-EDTA). The blood for biochemical examinations was put in special tubes without anticoagulants, and the serum was separated by centrifugation at $3000 \mathrm{rpm}$ for 10 minutes and after that the analysis of the selected serum parameters was performed. Determination of biochemical parameters was performed on a multiparametric biochemical analyzer Hitachi 750 (Tokyo, Japan) with tests from Boehringer Mannheim (Germany), while we used an analyzer ISE, Nova 5 (USA) and a set tests by Randox for the determination of serum electrolytes $(\mathrm{Ca}, \mathrm{Na}, \mathrm{K})$. The number of erythrocytes and leukocytes was determined in the Thoma-Zeiss chamber, the number of platelets in the Neubauer chamber, the value of hematocrit was 
determined by the Wintrobe method. Haemoglobin concentration was determined using the Sahli method.

The collected data were processed using statistical program Statistica 10 (StatSoft, USA). The following analyses were performed: statistical analysis of the obtained results, the analysis of variance by a standard procedure with testing of the statistical significance of the differences between certain groups and examined parameters by applying LSD test.

\section{RESULTS}

No health issues or pheasant deaths were recorded during the experiment. The results of chemical investigation of breast meat are shown in Table 2. Addition of organic selenium to pheasant diet resulted in relative higher values of breast muscle weight, electrochemical reactions of meat, water and fat content. However, statistically significant differences between treatments $(\mathrm{p}>0.05)$ were not recorded. The obtained results of breast meat weight indicate that the mass was the lowest in pheasants of the K group amounting $221.50 \mathrm{~g}$, and the highest was in $2^{\text {nd }}$ group of pheasants with $229.32 \mathrm{~g}$.

Table 2. Chemical composition of breast muscle and selenium concentration in meat

\begin{tabular}{|lccc|}
\hline $\begin{array}{c}\text { Group / } \\
\text { Chemical composition } \\
\text { of breast muscle meat }\end{array}$ & $\begin{array}{c}\text { K group } \\
\mathrm{n}=7\end{array}$ & $\begin{array}{c}\text { 1st group } \\
\mathrm{n}=7\end{array}$ & $\begin{array}{c}\text { 2nd group } \\
\mathrm{n}=7\end{array}$ \\
\hline Mass (g) & $221.50 \pm 28$ & $224.60 \pm 18$ & $229.42 \pm 32$ \\
\hline pH & $6.10 \pm 16$ & $6.02 \pm 32$ & $6.19 \pm 42$ \\
\hline Moisture (\%) & $72.63 \pm 23$ & $72.38 \pm 52$ & $72.49 \pm 55$ \\
\hline Fat (\%) & $1.08 \pm 56$ & $1.10 \pm 23$ & $1.11 \pm 36$ \\
\hline Total protein (\%) & $25.14 \pm 14$ & $25.15 \pm 11$ & $25.11 \pm 87$ \\
\hline Ash $(\%)$ & $1.18 \pm 41$ & $1.20 \pm 09$ & $1.20 \pm 23$ \\
\hline Selenium $(\mathbf{m g} / \mathbf{k g})$ & $0.121 \pm 13$ & $0.129 \pm 03$ & $0.135 \pm 33^{*}$ \\
\hline
\end{tabular}

${ }^{\star} \mathrm{p}<0.05 ;{ }^{* *} \mathrm{p}<0.01$

The results of selenium content in breast meat samples shown in Table 2 . indicate that the average selenium content was the lowest in the K group with $0.121 \mathrm{mg} / \mathrm{kg}$. It was slightly higher in the $1^{\text {st }}$ group with $0.129 \mathrm{mg} / \mathrm{kg}$ and the highest in the $2^{\text {nd }}$ group of pheasants with $0.135 \mathrm{mg} / \mathrm{kg}$. Statistical analysis of the data on selenium content in breast meat showed a statistically significant 
difference $(\mathrm{p}<0.05)$ among control $\mathrm{K}$ group which did not have organic selenium in feed and the $2^{\text {nd }}$ group of pheasants that had organic selenium in their food in the concentration of $0.3 \mathrm{mg} / \mathrm{kg}$.

The ability of water retention represents a very important trait of meat quality because yield, juiciness, taste and meat texture depend on it. The results of breast meat moisture loss are shown in Table 3. The best relative values of water retention in breast meat were achieved by the $2^{\text {nd }}$ group both after $24 \mathrm{~h}(1.17 \%)$ and after $48 \mathrm{~h}(1.93 \%)$ from the time of meat cooling. Therefore, in comparison with the K group it had better efficiency by $0.75 \%$. Similar results were achieved by the $1^{\text {st }}$ group, which had better water retention in meat by $0.58 \%$ compared to $\mathrm{K}$ group. The worst results were recorded in the $\mathrm{K}$ group which had relative value of water retention of $1.79 \%$ after $24 \mathrm{~h}$, and $2.68 \%$ after $48 \mathrm{~h}$.

Table 3. Moisture loss in pheasant breast meat

\begin{tabular}{|lcccccc|}
\hline \multirow{2}{*}{$\begin{array}{c}\text { Group/ } \\
\text { Water loss in meat }\end{array}$} & \multicolumn{2}{c}{$\begin{array}{c}\text { K group } \\
\mathrm{n}=7\end{array}$} & \multicolumn{2}{c}{$\begin{array}{c}\text { 1st group } \\
\mathrm{n}=7\end{array}$} & \multicolumn{2}{c|}{$\begin{array}{c}\text { 2nd group } \\
\mathrm{n}=7\end{array}$} \\
\cline { 2 - 8 } & $\mathrm{g}$ & $\%$ & $\mathrm{~g}$ & $\%$ & $\mathrm{G}$ & $\%$ \\
\hline $\begin{array}{l}\text { Water loss } \\
\text { after 24 h }\end{array}$ & 1.30 & 1.79 & 1.10 & 1.52 & 0.85 & 1.17 \\
\hline $\begin{array}{l}\text { Water loss } \\
\text { after 48 h }\end{array}$ & 1.95 & 2.68 & 1.70 & 2.10 & 1.40 & 1.93 \\
\hline Difference \% & - & - & - & 0.58 & - & 0.75 \\
\hline
\end{tabular}

A very important indicator of meat quality, besides chemical composition, are its sensory traits which were examined using the method of Rank test in this experiment, or meat acceptability by consumers whereby lower sum of ranks represents higher meat acceptability. The differences in assessment of the acceptability of pheasant's breast meat are displayed in Table 4 . When it comes to ranking of breast meat samples, the samples of the $2^{\text {nd }}$ group (32 points) were assessed as the most acceptable, and this group had the highest difference in the sum of ranks of 15 points. It was followed by the $1^{\text {st }}$ group of pheasants (39 points) with the difference in the sum of ranks of 7 points in comparison to the $\mathrm{K}$ group, and as the least acceptable were the breast meat samples of the K group (47 points). 
Table 4. Total acceptability assessment of pheasant's breast meat (Rank test)

\begin{tabular}{|lccc|}
\hline \multirow{3}{*}{ Group } & $\begin{array}{c}\text { K group } \\
\mathrm{n}=7\end{array}$ & $\begin{array}{c}\text { 1st group } \\
\mathrm{n}=7\end{array}$ & $\begin{array}{c}\text { 2nd group } \\
\mathrm{n}=7\end{array}$ \\
\cline { 2 - 4 } & \multicolumn{3}{c}{ The sum of ranks } \\
\hline K group & - & 39 & 32 \\
\hline 1st group & - & 8 & 15 \\
\hline 2nd group & - & - & 7 \\
\hline
\end{tabular}

Haematological examinations of shaped blood elements (Table 5) show similar values and insignificant differences $(p>0.05)$ between the examined groups of pheasants. The number of erythrocytes (RBC- Red Blood Cells) varied within relatively narrow limits in all the groups from $2.15 \times 10^{6} / \mathrm{mm}^{3}$ in the $1^{\text {st }}$ group to $2.32 \times 10^{6} / \mathrm{mm}^{3}$ in the $2^{\text {nd }}$ group of pheasants. Similar results were also recorded for the average values of the number of leukocytes (WBC - White Blood Cells), which ranged from $21.30 \times 10^{3} / \mathrm{mm}^{3}$ in the $1^{\text {st }}$ group to $21.50 \times 10^{3} / \mathrm{mm}^{3}$ in the $2^{\text {nd }}$ group of pheasants. These are the figures that vary within normal physiological values for this species of birds. The other examined parameters in all groups, such as number of platelets (PLT), haemoglobin (MCH- Mean Corpuscular Hemoglobin) and haematocrit (HCT - Haematocrit-Packed cell volume) also had uniform median values without statistical significance both between control and experimental groups, and between groups with different treatments with organic selenium. The platelet number was the lowest in the $2^{\text {nd }}$ group with $28.40 \times 10^{3} / \mathrm{mm}^{3}$, followed by $\mathrm{K}$ group with $28.60 \times 10^{3} / \mathrm{mm}^{3}$, and the highest was in the $1^{\text {st }}$ group where organic selenium was added at the concentration of $0.2 \mathrm{mg} / \mathrm{kg}$ and it was $29.20 \times 10^{3} / \mathrm{mm}^{3}$. Haematocrit had average values of $38.3 \%$ in K group, $37.10 \%$ in the $1^{\text {st }}$ group and $38.20 \%$ in the $2^{\text {nd }}$ group of pheasant blood. The concentration of haemoglobin had the lowest average value of $125 \mathrm{~g} / \mathrm{L}$ in the $1^{\text {st }}$ group, followed by 129 $\mathrm{g} / \mathrm{L}$ in $\mathrm{K}$ group and the highest average value of $130 \mathrm{~g} / \mathrm{L}$ was determined in the pheasants blood of the $2^{\text {nd }}$ group. 
Table 5. Haematological parameters of pheasants

\begin{tabular}{|c|c|c|c|}
\hline $\begin{array}{l}\text { Haematologi- } \\
\text { cal parameters }\end{array}$ & $\begin{array}{c}\text { K group } \\
n=7\end{array}$ & $\begin{array}{c}\text { 1st group } \\
n=7\end{array}$ & $\begin{array}{c}\text { 2nd group } \\
n=7\end{array}$ \\
\hline $\mathrm{RBC}(\mathrm{x} \mathrm{106/ \textrm {mm } 3 )}$ & $2.27 \pm 0.15$ & $2.15 \pm 0.28$ & $2.32 \pm 0.45$ \\
\hline $\mathrm{WBC}(\mathrm{x} 103 / \mathrm{mm} 3)$ & $21.40 \pm 2.65$ & $21.30 \pm 1.30$ & $21.50 \pm 2.20$ \\
\hline PLT (x 103/ mm3) & $28.60 \pm 40$ & $29.20 \pm 70$ & $28.40 \pm 50$ \\
\hline $\mathrm{MCH}(\mathrm{g} / \mathrm{l})$ & $129.00 \pm 1.80$ & $125.00 \pm 2.30$ & $130.00 \pm 1.50$ \\
\hline HCT (\%) & $38.30 \pm 0.73$ & $37.10 \pm 0.24$ & $38.20 \pm 0.35$ \\
\hline
\end{tabular}

${ }^{*} p<0.05 ; * * p<0.01$

Table 6. Biochemical parameters of pheasant blood

\begin{tabular}{|lccc|}
\hline \multicolumn{1}{|c}{ Parameters } & $\begin{array}{c}\text { K group } \\
\mathrm{n}=7\end{array}$ & $\begin{array}{c}\text { 1st group } \\
\mathrm{n}=7\end{array}$ & $\begin{array}{c}\text { 2nd group } \\
\mathrm{n}=7\end{array}$ \\
\hline GLU $(\mathbf{m M} / \mathbf{L})$ & $18.50 \pm 0.65$ & $18.10 \pm 0.80$ & $17.60 \pm 0.30$ \\
\hline AST $(\mathrm{U} / \mathrm{L})$ & $250.00 \pm 1.52$ & $263.00 \pm 1.41$ & $257.00 \pm 2.15$ \\
\hline ALT $(\mathbf{U} / \mathbf{L})$ & $9.20 \pm 0.48$ & $10.00 \pm 0.16$ & $8.90 \pm 0.27$ \\
\hline TP $(\mathbf{g} / \mathbf{l})$ & $36.50 \pm 1.23$ & $35.80 \pm 0.98$ & $37.0 \pm 1.10$ \\
\hline ALB - Albumin $(\mathbf{g} / \mathbf{l})$ & $14.50 \pm 0.14$ & $14.20 \pm 0.21$ & $14.80 \pm 0.11$ \\
\hline CHOL $(\mathbf{m M} / \mathbf{L})$ & $3.53 \pm 0.12$ & $3.51 \pm 0.16$ & $3.40 \pm 0.23$ \\
\hline Triglycerides $(\mathbf{m M} / \mathbf{L})$ & $0.93 \pm 0.24$ & $0.84 \pm 0.15$ & $0.87 \pm 0.20$ \\
\hline Ca $(\mathbf{m M} / \mathbf{L})$ & $2.28 \pm 0.10$ & $2.30 \pm 0.25$ & $2.30 \pm 0.15$ \\
\hline $\mathbf{K}(\mathbf{m M} / \mathbf{L})$ & $3.90 \pm 0.21$ & $3.82 \pm 0.15$ & $3.92 \pm 0.38$ \\
\hline $\mathbf{N a}(\mathbf{m M} / \mathbf{L})$ & $149.45 \pm 1.54$ & $147.20 \pm 0.20$ & $151.10 \pm 0.80$ \\
\hline Se $(\boldsymbol{\mu g} / \mathbf{m l})$ & $0.137 \pm 0.12$ & $0.141 \pm 0.05$ & $0.145 \pm 0.24^{*}$ \\
\hline
\end{tabular}

${ }^{*} \mathrm{p}<0.05 ;{ }^{* *} \mathrm{p}<0.01$

According to the results shown in Table 6, the highest average value of glucose (GLU) concentration was recorded by K group, which amounted 18.50 $\mathrm{mmol} / \mathrm{L}$, followed by $18.10 \mathrm{mmol} / \mathrm{L}$ in the $1^{\text {st }}$ group and the lowest value of $17.60 \mathrm{mmol} / \mathrm{L}$ was determined in the $2^{\text {nd }}$ group. No statistically significant differences were found between the analysed groups ( $p>0.05)$. The highest values of the examined blood serum enzymes were found in pheasants of the $1^{\text {st }}$ experimental group. Those pheasants consumed organic selenium from food at the concentration of $0.2 \mathrm{mg} / \mathrm{kg}$ of mixture with the average AST value of $263.00 \mathrm{U} / \mathrm{L}$, and the value of alanine aminotransferase (ALT) was $10.00 \mathrm{U} / \mathrm{L}$. 
The selenium added to the food resulted in insignificant increase in the values of aspartate aminotransferase (AST) and ALT in the $1^{\text {st }}$ experimental group of pheasants but with no statistical significance compared to the other two experimental groups $(\mathrm{p}>0.05)$.

Total proteins and albumin concentrations in our experiments had the highest values in blood serum of the $2^{\text {nd }}$ group of pheasants whose feed contained $0.3 \mathrm{mg} / \mathrm{kg}$ of selenium. The analysis of variance did not show any significant differences between treatments $(\mathrm{p}>0.05)$. Cholesterol and triglyceride concentrations ranged within normal physiological limits and without determined statistic differences between average values of the examined groups of pheasants. The part of our examinations related to monitoring of the concentrations of selected cation electrolytes of pheasant serum $(\mathrm{Ca}, \mathrm{K}$ and $\mathrm{Na})$ is shown in Table 6. The concentrations of examined electrolytes in blood serum were rather uniform in all pheasant groups, so statistical analysis showed no significant differences between median values of the examined groups of pheasants $(\mathrm{p}>0.05)$.

The most reliable criterion for selenium status in animals is considered to be the determination of selenium concentration in the blood and tissues of birds and animals. In our research the average content of selenium in blood serum of the $2^{\text {nd }}$ group of pheasants was $0.145 \mu \mathrm{g} / \mathrm{mL}$ and it was statistically significantly higher $(\mathrm{p}<0.05)$ than the average content of selenium in blood serums of $\mathrm{K}$ group of pheasants where its value amounted $0.137 \mu \mathrm{g} / \mathrm{mL}$. There was no statistical significance between the average content of selenium in blood serum of $\mathrm{K}$ group and the $1^{\text {st }}$ group of pheasants despite the fact that the average value of selenium in blood serum was higher than in the K group of pheasants $(0.141 \mu \mathrm{g} / \mathrm{mL})$.

\section{DISCUSSION}

No deaths of the examined pheasants were registered during the experiment. As this was an older age category of experimental pheasants, it cannot be confirmed with certainty, based on our data on mortality, that selenium from feed does not affect mortality, because the literature shows that the biggest losses are in chickens and that mortality rates in older categories are much lower (Ristić, 2005).

The relative uniformity of chemical composition of breast meat in terms of the content of the analysed parameters between the examined groups of pheasants is in accordance with the research of Cvrtila et al. (2007). In our experiments, no statistically significant differences were determined between the treatments $(\mathrm{p}>0.05)$ of the examined chemical parameters of meat. Tucak et al. (2008) state that the body weight of adult pheasants raised in an avi- 
ary ranging from 969 to $1,144 \mathrm{~g}$ and the breast meat weight varied between 248 and $295 \mathrm{~g}$. These authors determined higher values of protein, fat and ash in breast meat of pheasants in comparison to our results. In our experiment, the protein and fat concentration in pheasant meat were uniform, whereas the protein content was higher than the fat content. The results we obtained are in accordance with other researchers who stated that wild populations and farmraised pheasants are distinguished by higher protein and lower fat content in meat, which represents a characteristic of this bird species (Hofbauer et al., 2010; Franco and Lorenzo, 2013).

Organically bound selenium in the form of selenomethionine has a strong antioxidant effect in poultry organisms, directly affecting the increase in the concentration of GPx in the liver and decrease in the concentration of lipid peroxidase, resulting in the meat of exceptional quality with high content of selenium. Several researchers have confirmed the positive effect of increasing the concentration of selenium in musculature of broilers whose feed was treated with organic selenium compared to control group without supplement or with inorganic selenium supplementation in food (Edens and Kymberly, 2004; Payne and Southern, 2005; Dlouha et al., 2008).

Our research confirmed the positive antioxidant effect of selenium on the musculature of the breast meat because the $1^{\text {st }}$ group and the $2^{\text {nd }}$ group of pheasant samples contained less water loss during storage. Meat quality can successfully be preserved during storage by adding selenium antioxidants to the feed of domestic animals, because selenium is deposited in musculature cells, which improves the ability of the cells to retain water (Surai, 2000). According to Edens (2001), selenium in the muscle tissue reduces fat peroxidation during meat storage and in that way it affects the preservation of meat quality. Organic selenium in the form of selenomethionine has a positive effect on meat quality because it increases the activity of glutathione peroxidase (GSH-Pk) and keeps lipid peroxidase at a low level, which results in cell membrane stability and the ability to bind water (Edens et al., 2000; Edens and Kymberly, 2004).

Based on the Rang test results obtained in these research studies, it can be concluded that the addition of organic selenium to feed or diet had a positive effect on acceptability of pheasant meat. According to many authors, the compounds that are the carriers of smell and taste have the greatest effect on food acceptability (Baltić, 1993; Ivanović et al., 2012). The supplementation of organic selenium in feed has a positive effect on the appearance, juiciness, smell and colour of meat (Surai and Dvorska, 2002), while the increased juiciness is the result of better water retention in meat (Džinić et al., 2006).

Determination of haematological parameters is a reliable indicator of the physiological condition of animal organisms and the impact of certain 
supplements on blood chemistry. These parameters can be affected by different factors such as nutrition, diseases, gender, age, physical activity and ambient conditions (Kaneko, 1989; Jovanović, 1990). Recognizing the change in the number of leukocytes is of particular significance, whether it is an increase or decrease in their number, it is always a certain pathological phenomenon in the organism (Harr, 2002). In the conditions of temperature stress, organic selenium has a positive effect on reducing the effect of this negative ambient factor, so the level of leukocytes in blood does not change, but increases food consumption and the level of glutathione peroxidase, which has a defensive role (Mahmoud and Edens, 2003). Our data are in accordance with the research of Šperanda et al. (2005) who established that selenium ( $0.2 \mathrm{mg}$ organic selenium/kg diet) did not have any effect on erythrocytes and leukocytes count values. The obtained average values of haematological parameters were in accordance with normal physiological values and the results published by other authors (Schmidt et al.2007; Hauptmanova et al. 2006; Kececi and Ramazan, 2011). Based on the results obtained in these studies, it can be concluded that the application of organic selenium as food additive did not affect the haematological blood parameters of the examined pheasants.

The part of the examination related to the analysis of biochemical parameters of pheasant blood serum (glucose, AST and ALT enzymes, total protein concentration, total cholesterol, albumin, triglycerides, $\mathrm{Ca}, \mathrm{K}$ and $\mathrm{Na}$ ) which are shown in Table 6, indicates that the majority of these parameters had the values which ranged within normal physiological limits and which were reported by other authors (Šperanda et al., 2005; Loyd and Gibson, 2006; Suchy et al., 2010). The variations in the concentration of some blood constituents in birds and animals indicate the changes in physiological and biochemical homeostasis of an organism. By analysing these parameters, it is relatively easy to determine the health status of animals and the deficiency of nutrients.

Glucose is a very important energetic material of all living systems, considering that all cells have enzymes for their catalytic decomposition. The normal range of glucose concentration for most birds is between 11.1 and $27.8 \mathrm{mmol} / \mathrm{L}$ (Coles, 1977). The results we obtained in our research are in accordance with the data of the other authors (Loyd and Gibson, 2006; Šperanda et al., 2005) and indicate that by adding selenium normal glucose homeostasis is maintained.

Significant biochemical parameters of blood serum are the activity of the AST and ALT enzymes which are found in bird organisms in the liver, blood, cerebrospinal fluid and urine. The liver is very sensitive to increased concentrations of nutrients and toxins. Any increase in the activity of these enzymes in blood serum indicates pathological changes primarily in the hepatobiliary tract, liver damage, heart and skeletal muscles (Kaneko, 1989; Dukes, 1993; Moss et al., 1997). 
The concentrations of total proteins are of great significance in the diagnosis of liver and kidney disease, metabolic and nutritional disorders which lead to the loss of protein in the organism reduced protein synthesis and increased decomposition (Kaneko, 1989; Dukes, 1993). The results we obtained in our research are in line with the data of other authors (Šperanda et al., 2005) who determined that selenium results in a partial increase of total proteins and albumin, but does not cause statistically significant differences.

Cholesterol is found in all organism cells, and main organs where about $90 \%$ of it is synthesized are the liver and intestines. Triglycerides play important roles in bird organisms, serving as metabolic fuel and components of cell membranes (Jovanović 1990; Dukes, 1993). According to available literature data, organic selenium supplementation in pheasant diet does not lead to disorder of normal physiological cholesterol and triglycerides levels in serum (Šperanda et al. 2005), which is in accordance with the results obtained in this experiment. Cholesterol and triglyceride levels determined in this research were lower than the data presented by Kecci and Ramazan (2001) and Šperanda et al. (2005), but they had similar values to those found by Lloyd and Gibson (2006).

The physiological effect of blood electrolytes is of great importance for the health, productivity and maintenance of normal homeostasis of an organism. Serum electrolyte concentrations can indicate disorder in the functioning of certain organs and systems especially in the functioning of intestinal tract, kidneys and cell homeostasis (Kaneko, 1989; Dukes, 1993). The obtained concentrations of pheasant serum electrolytes were within normal physiological limits for this species of birds. They match the data stated by Šperanda et al. (2005), Lloyd and Gibson (2006).

The significance of selenium as pheasant food supplement and its content in the blood is very scantily described in the available literature. We achieved significantly higher concentration of selenium in the blood of pheasants by adding organic selenium to their feed at the concentration of $0.3 \mathrm{mg} / \mathrm{kg}$ of food compared to the blood of K group whose food did not contain selenium. Similar results were presented by Payne and Southern (2005) and Marković et al. (2008). At the same time, in comparison with inorganic selenium which was added in the feed in the same concentration, Marković et al. (2008) determined a higher concentration of selenium in the blood of broiler groups where organic selenium was added to the food. Based on our research and obtained values of selenium in the blood serum of the examined pheasants, it can be concluded that organic selenium added in concentrations of 0.2 and $0.3 \mathrm{mg} /$ $\mathrm{kg}$ in the food led to an increase in its value in the blood serum. Therefore, the concentration of $0.3 \mathrm{mg} / \mathrm{kg}$ in food in the $2^{\text {nd }}$ group of pheasants caused 
significant difference $(\mathrm{p}<0.05)$ compared to the $\mathrm{K}$ group of pheasants which were fed without selenium supplement in food.

By the analysis of the majority of examined biochemical indicators of pheasant blood serum, apart from selenium concentration, we did not observe other statistically significant differences between the values for the K group and the pheasant groups whose food contained organic selenium, which is in accordance with Šperanda et al. (2005). The measured parameters of blood serum, apart from selenium concentration, were within the limits of reference values for pheasants, which indicates that selenium supplementation in pheasant food does not affect the examined parameters of pheasants blood serum.

\section{CONCLUSION}

Based on all of the above mentioned, we can generally conclude that the examined impact of different doses of organic selenium in pheasant feed or diet, applied in the concentrations of $0.2 \mathrm{mg} / \mathrm{kg}$ and $0.3 \mathrm{mg} / \mathrm{kg}$, did not have any noticeable effect on the values of biochemical parameters of blood serum and haematological blood parameters. The addition of organic selenium in pheasant feed did not have any statistical significance on chemical quality of pheasant breast meat muscle. The results of the research of the effect of organic selenium from the feed at the concentration of $0.3 \mathrm{mg} / \mathrm{kg}$ on its content in the breast meat and blood serum of pheasants indicate statistical significance $(p>0.05)$ compared to the parameters of the control group of pheasants which were fed without selenium supplement. The justification of this research is reflected in obtaining required concentrations of selenium in pheasant meat and the production of nutritionally important selenized meat for human consumption.

\section{Author's Contribution:}

S.O., B.S. and N.Đ. made contributions to conception and design of the article and draft ed the manuscript; B.P. made substantial contributions to the basic idea; M.R. carried out the chemical analyses; V.Đ. was involved in draft ing of the manuscript; S.O. collected the samples and experimental data; V.Ž. did statistical analysis. All the authors have read and approved the final manuscript.

\section{Competing interest}

The authors declare that they have no competing interests. 


\section{REFERENCES}

1. AOAC, Association of Official Analytical Chemists. 1990. Official Methods of Analysis, ed by Kenneth Helrich, AOAC, Arlington, Virginia, USA, 15th ed, 246. ISBN 0-935584-42-0.

2. Baltić, M., Teodorović, B.V. 1997. Higijena mesa riba, rakova i školjki, Veterinarski fakultet Beograd, 250. ISBN 56-81043-01-3.

3. Baltić, Ž.M. 1993. Kontrola namirnica, Institut za higijenu i tehnologiju mesa, Beograd.

4. Barroeta A.C. 2006. Nutritive value of poultry meat: Relationship between vitamin E and PUFA. World's Poultry Science Journal, 63, 277-284. doi:10.1017/S0043933907001468.

5. Coles, H. Brian. 1977. Avian medicine and surgery, Wiley-Blackwell, 2nd edition (January 15, 1997), Blackwell Science Ltd, a Blackwell Publishing company, 408. ISBN 10:0632033568.

6. Cvrtila Ž., Hadžiosmanović M., Kozačinski L., Zdolec N., Filipović I., Severin K., Mašek T. 2007. Kemijski sastav mesa fazanskih kopuna. Meso, 9 , 3, 148-151. doi:10.31727/m.

7. Dlouha G., Ševčikova S., Dokoupilova A., Zita L., Heindl J., Skrivan M. 2008. Effect of dietary selenium sources on growth performance, breast muscle selenium, glutathione peroxidase activity and oxidative stability in broilers. Czech Journal Animal Scinces, 53, 6, 265-269. doi:10.17221/361CJAS.

8. Dukes H.H. 1993. Physiology of Domestic Animals, Editor: Swenson J. Melvin, Reece O. William, Ithaca, USA, 11th Edition, 962, ISBN 10:0801428041.

9. Džinić N., Tomović V., Petrović Lj., Perić L. 2006. Uticaj dodataka selena različitog porekla u hranu za piliće na kvalitet $\mathrm{m}$. pectoralis. Tehnologija mesa, 47, 5-6, 199-203.

10. Edens, F.W. 1997. Potential for organic selenium to replace, selenite, in poultry diets. Zootecnica International, 20, 28-31. https://zootecnicainternational.com/online-magazine.

11. Edens F.W., Carter T.A., Parkhurst C.R., Sefton A.E. 2000. Effect of selenium source and litter type on broiler feathering. Journal of Applied Poultry, 9, 407-413. doi:10.1093/japr/9.3.407.

12. Edens F.W. 2001. Involvement of Sel-Plex in physiological stability and performance of broiler chickens. In Proceedings of Altech's 12th Annual Symposium, Biotechnology in the Feed Industry, Eds. Lyon T.P. and Jacques K.A., Nottingham University Press, Nottingham, UK, 349-376. ISBN-10:1897676360. 
13. Edens F.W., Kymberly M. Gowdy. 2004. Selenium sources and selenoproteins in practical poultry production. Nutritional Biotechnology in the Feed and Food Industries. In Proceedings of Alltech's Twentieth Annual Symposium, Edited by TP Lyons and KA Jacques, Typeset by Nottingham University Press, Nottingham, England, 35-56. ISBN 1-904761-27-5.

14. Franco D., Lorenzo J. M. 2013. Meat quality and nutritional composition of pheasants (Phasianus colchicus) reared in an extensive system. British Poultry Science, 54, 594-602. doi.org/10.1080/00071668.2013.828195.

15. Harr E. Kendal. 2002. Clinical chemistry of companion avian species: A Review. Veterinary clinical pathology, 31, 140-151. doi:10.1111/j.1939165x.2002.tb00295.x.

16. Hauptmanova K., Maly M., Literak I. 2006. Changes of haematological parameters in common pheasant throughout the year. Veterinarni Medicina Czech, 51, 1, 29-34. doi.org/10.17221/5514-VETMED.

17. Hofbauer P., Smulders F. J. M., Vodnansky M., Paulsen P., El-Ghareeb W. R. 2010. A note on meat quality traits of pheasants (Phasianus colchicus). European Journal of Wildlife Research. 56, 809-813. doi: 10.1007/s10344010-0396-7.

18. INRA-AFZ 2004: http://www.feedtables.com

19. Ivanović, S., Teodorović, V., Baltić, Ž. M. 2012. Kvalitet mesa (biološke i hemijske opasnosti), Naučni institut za veterinarstvo Srbije, Beograd, 356. ISBN 978-86-81761-51-9.

20. Jovanović, M. 1990. Fizologija domaćih životinja, Medicinska knjiga, Beograd-Zagreb, 687. YU ISBN 86-311-0056-0.

21. Kaneko, J. 1989. Clinical Biochemistry of Domestic Animals, 4th Edition, Academic Press, San Diego, 932. ISBN 9780080529196.

22. Kang B.P.S., Mehta U., Bansal M.P. 2000. Hyperlipidemia and Type-1-5'monodeiodinase activity: Regulation by selenium supplementation in rabbits. Biological Trace Element Research, 77, 231-239. doi: 10.1385/ BTER:77:3:231.

23. Kececi T., Ramazan C. 2011. Haematological and biochemical values of the blood of pheasants (Phasianus colchicus) of different ages. Turkish Journal Veterinary Animal Sciences. 2011; 35, 3, 149-156. doi:10.3906/vet-0910-135.

24. Lloyd, S., Gibson, J.S. 2006. Haematology and biochemistry in healthy young pheasants and red-legged partridges and effects of spironucleosis on these parameters. Avian Pathology, 35, 335-340. doi: $10.1080 / 03079450600821794$.

25. Mahmoud K. and Edens F.W. 2003. Influence of selenium sources on agerelated and mild heat stress-related changes of blood and liver glutathione redox cycle in broiler chickens (gallus domesticus). Comparative bioche- 
mistry and physiology. Part B, Biochemistry \& molecular biology, 136, 921-934. doi: 10.1016/s1096-4959(03)00288-4.

26. Marković R., Jovanović B.I., Baltić Ž. M., Šefer D., Petrujkić B, Sinovec Z. 2008. Effects of selenium supplementation as sodium selenite or selenized yeast and different amounts of vitamin $\mathrm{E}$ on selenium and vitamin $\mathrm{E}$ status of broilers. Acta Veterinaria (Beograd), 58. 4, 369-380. doi:10.2298/ AVB0801063S.

27. Moss, D.W., Handerson, A.R., Kachmar, J.F. 1997. Enzimi. U Osnovi kliničke hemije, udžbenik. Tietz W. Norbert, Ortomedics, Beograd, 360-444. ISBN 0-7216-8862-4.

28. National Research Council NRC. 1994. Nutrient Requirements of Poultry. The National Academies Press, Washington, DC, 9th edition, 176. ISBN 978-0-309-04892-7.

29. Payne R.L., and Southern L.L, 2005. Comparison of inorganic and organic selenium sources for broilers. Poultry Science, 84, 898-902. doi: 10. 1093/ ps/84.6.898.

30. Rulebook on quality of poultry meat. Official Gazette SFRJ. 1981, No 1.

31. Rulebook on quality of poultry meat. Official Gazette SFRJ. 1988, No 51.

32. Ristić Z. 2005. Monografija Fazan, Biblioteka Memorija, Sombor, 592. ISBN 86-83485-09-9.

33. Schmidt E.M.S., Paulillo A.C., Dittrich R.L., Santin E., da Silva P.C.L., Beltrame O., de Oliveira E.G. 2007. The effect of age on hematological and serum biochemical values on juvenile ring-necked pheasants (Phasianus colchicus). International Journal of Poultry Science, 6, 459-461. doi:10.3923/ijps.2007.459.461.

34. Silva C.M.G., Gloria M.B.A. 2002. Bioactive amines in chicken breast and thigh after slaughter and during storage at $4{ }^{\circ} \mathrm{C}$ and in chicken-based meat product. Food Chemistry, 78, 2, 241-248. doi:10.1016/S03088146(01)00404-6.

35. Skrivan M., Dlouha G., Mašata O., Ševčikova S. 2008. Effect of dietary selenium on lipid oxidation, selenium and vitamin $\mathrm{E}$ content in the meat of broiler chickens. Czech Journal of Animal Science, 53, 7, 306-311. doi:10.17221/358-CJAS.

36. Šperanda M., Florijančić T., Bošković I., Bogut I., Gutzmirtl H., Senčić Đ., Antunović Z., Bodakoš D. 2005. Utjecaj organskog selena na rast i biokemijske pokazatelje u serumu fazanskih pilića. Krmiva, 47, 6, 295-301. doi:org/10.33128/k.

37. SRPS EN 14627:2008. Hrana za životinje. Određivanje selena atomskom apsorpcionom spektrometrijom sa hidridnom tehnikom (HGAAS) posle mikrotalasne digestije 
38. SRPS EN ISO 8587/2006. Sensory analysis - Methodology - Ranking.

39. SRPS ISO 1442/1998. Meso i proizvodi od mesa. Određivanje sadržaja vlage.

40. SRPS ISO 1443/1992. Meso i proizvodi od mesa. Određivanje sadržaja ukupne masti.

41. SRPS ISO 2917/2004. Meso i proizvodi od mesa. Merenje pH vrednosti (referentna metoda).

42. SRPS ISO 6490-1/2001. Hrana za životinje. Određivanje sadržaja kalcijuma, volumetrijska metoda.

43. SRPS ISO 6491/2002. Hrana za životinje. Određivanje sadržaja fosfora, spektrometrijska metoda.

44. SRPS ISO 936/1999. Meso i proizvodi od mesa. Određivanje ukupnog pepela.

45. SRPS ISO 937/1992. Meso i proizvodi od mesa. Određivanje sadržaja azota (referentna metoda).

46. Suchy P., Strakova E., Kroupa L., Steinhauser L., Herzig I. 2010. Values of selected biochemical and mineral metabolism indicators in feathered game. Acta Veterinaria Brno. 79,9, 9-12. doi:10.2754/avb201079S9S009.

47. Surai P.F. 2000. Organic selenium: benefits to animals and humans, a biochemist's view. In Proceedings of Alltech's 16th Annual Symposium, Biotechnology in the Feed Industry, The Future of Food, Eds. Lyons, T.P. and Jacques, K.A., Nottingham University Press, Nottingham, UK, 205-260. ISBN 10:1897676751.

48. Surai P. F. and Dvorska, J. E. 2002. Effect of selenium and vitamin E content of the diet on lipid peroxidation in breast muscle tissue of broiler breeder hens during storage. In Proceedings of Australian Poultry Science Symposium, editors R.A. Pym, World Poultry Science Association, Volume 14, 187-192.

49. Surai P.F. 2007. Selenium in poultry nutrition 2. Reproduction, egg and meat quality and practical applications. World's Poultry Science Journal, 58, 4, 431-450. doi:10.1079/WPS20020032.

50. Tucak Z., Skrivanko M., Posavcevic S., Periskić M., Bošković I., Jumić V. 2008. Influence of keeping pheasants in captivity vs. nature on the biological value of meat and its use in human nutrition. Collegium Antropologicum, 32 3: 959-962.

Received: 24.03.2021.

Accepted: 10.06.2021. 